\title{
Drug Induced Induction of Labor
}

National Cancer Institute

\section{Source}

National Cancer Institute. Drug Induced Induction of Labor. NCI Thesaurus. Code C92768.

Using pharmaceutical agents to influence uterine contractions and start labor during the childbirth process. 